\title{
Study of biodegradation of Poly(butylene adipate co-terephthalate) (PBAT) by maritime microorganisms from the Atlhantic Coast of Recife-PE (Brazil)
}

\author{
Estudo da biodegradação do Poli(butileno adipato co-tereftalato) (PBAT) por microrganismos \\ marítimos do Litoral Atlântico do Recife-PE (Brasil) \\ Estudio de biodegradación de Poli(co-tereftalato de adipato de butileno) (PBAT) por \\ microorganismos marítimos La Costa Atlántica de Recife-PE (Brasil)
}

Received: 12/09/2021 | Reviewed: 12/14/2021 | Accept: 12/15/2021| Published: 12/22/2021

\author{
Lhaira Souza Barreto \\ ORCID: https://orcid.org/0000-0001-6980-9631 \\ University of Pernambuco, Brazil \\ E-mail: 1haira.barreto@ufpe.br \\ Erika Emanuele Gomes da Silva \\ ORCID: https://orcid.org/0000-0003-4544-2200 \\ University of Pernambuco, Brazil \\ E-mail: erikamanu-gomes@hotmail.com \\ Mariana Alves Henrique \\ ORCID: https://orcid.org/0000-0003-1061-6717 \\ University of Pernambuco, Brazil \\ E-mail: mariana.ahenrique@ufpe.br \\ Josiane Dantas Viana Barbosa \\ ORCID: https://orcid.org/0000-0002-7423-5326 \\ Faculty of Technology SENAI CIMATEC, Brazil \\ E-mail: josianedantas@fieb.org.br \\ Sara Horácio de Oliveira \\ ORCID: https://orcid.org/0000-0002-5373-3860 \\ University of Pernambuco, Brazil \\ E-mail: sara.holiveira@ufpe.br \\ Yêda Medeiros Barbosa de Almeida \\ ORCID: https://orcid.org/0000-0003-1041-7144 \\ University of Pernambuco, Brazil \\ E-mail: yeda@ufpe.br \\ Glória Maria Vinhas \\ ORCID: https://orcid.org/0000-0001-5073-609X \\ University of Pernambuco, Brazil \\ E-mail: gloria.vinhas@ufpe.br
}

\begin{abstract}
Biodegradable polymers undergo a degradation process resulting from the action of microorganisms such as bacteria, fungi and algae. Poly(butylene adipate co-terephthalate) (PBAT) is considered a biodegradable synthetic polymer, even if its degradation has been confirmed under industrial composting conditions, the investigation of its degradation in the marine environment is still limited. Therefore, this work aims to study the biodegradation in the marine environment, of the biodegradable polymer (PBAT), and for that, it was submerged in a static system, using seawater from the coastal region of Pernambuco/Brazil as a fluid. The samples were studied by chemical, thermal and microbiological analyses, after 7, 14, 30, 90, 120 and 180 days of immersion. Microbiological analyzes indicated that aerobic heterotrophic bacteria (AHB), anaerobic heterotrophic bacteria (AnHB) and iron precipitating bacteria (IPB) were quantified in the system at all times at high concentrations, with the exception of Sulfate reducing bacteria (SRB), fungi and Pseudomonas that showed lower concentrations compared to other bacterial groups. Biodegradation was observed by the percentage of mass loss of approximately $2.25 \%$. In the DSC, the expansion of melting peaks after exposure to the marine environment was noted, while the TGA did not show changes in the curve trends. The FTIR showed that no new band appeared, nor displacement, since the vibrations of the covalent bonds of the groups are present regardless of the biodegradation. Indicating that no significant microbiological degradation of PBAT was observed.
\end{abstract}

Keywords: Biodegradation; Polymers; PBAT; Microorganisms; Marine environment. 


\begin{abstract}
Resumo
Os polímeros biodegradáveis passam por um processo de degradação resultante da ação de microrganismos tais como bactérias, fungos e algas. O Poli(butileno adipato co-tereftalato) (PBAT) é considerado um polímero sintético biodegradado, mesmo que sua degradação tenha sido confirmada em condições de compostagem industrial, a investigação de sua degradação em ambiente marinho ainda é limitada. Diante disso, esse trabalho tem como objetivo estudar a biodegradação no ambiente marinho, do polímero biodegradável (PBAT), e para isso, este foi submerso em sistema estático, utilizando como fluido a água do mar da Região Litorânea de Pernambuco/Brasil. As amostras foram estudadas por análises químicas, térmicas e microbiológicas, após 7, 14, 30, 90, 120 e 180 dias de imersão. As análises microbiológicas indicaram que as bactérias aeróbias heterotróficas (BHA), bactérias anaeróbias heterotróficas (BHAn) e bactérias precipitantes de ferro (BPF) foram quantificadas no sistema em todos os tempos em altas concentrações, com exceção das bactérias redutoras de Sulfato (BRS), fungos e Pseudomonas que apresentaram concentrações mais baixas em relação aos outros grupos bacterianos. A biodegradação foi observada pelo percentual de perda de massa em aproximadamente $2,25 \%$. No DSC foi notado a ampliação de picos de fusão após a exposição ao ambiente marinho, já o TGA não apresentou alterações nas tendências das curvas. O FTIR mostrou que não ocorreu o aparecimento de nenhuma nova banda, nem deslocamento, uma vez que as vibrações das ligações covalentes dos grupos estão presentes independente da biodegradação. Indicando que nenhuma degradação microbiológica significativa do PBAT foi observada.
\end{abstract}

Palavras-chave: Biodegradação; Polímeros; PBAT; Microrgamismos; Ambiente marinho.

\title{
Resumen
}

Los polímeros biodegradables sufren un proceso de degradación resultante de la acción de microorganismos como bacterias, hongos y algas. El poli (co-tereftalato de adipato de butileno) (PBAT) se considera un polímero sintético biodegradable, aunque su degradación se haya confirmado en condiciones de compostaje industrial, la investigación de su degradación en el medio marino aún es limitada. Por tanto, este trabajo tiene como objetivo estudiar la biodegradación en el medio marino, del polímero biodegradable (PBAT), y para ello, se sumergió en un sistema estático, utilizando como fluido agua de mar de la región costera de Pernambuco/Brasil. Las muestras fueron estudiadas mediante análisis químicos, térmicos y microbiológicos, luego de 7, 14, 30, 90, 120 y 180 días de inmersión. Los análisis microbiológicos indicaron que las bacterias heterótrofas aeróbicas (BHA), las bacterias heterótrofas anaeróbicas (BHAn) y las bacterias precipitadoras de hierro (BPH) se cuantificaron en el sistema en todo momento en altas concentraciones, a excepción de las bacterias reductoras de sulfato (BRS), hongos y Pseudomonas. que mostró concentraciones más bajas en comparación con otros grupos bacterianos. La biodegradación se observó por el porcentaje de pérdida de masa de aproximadamente 2,25\%. En el DSC, se observó la expansión de los picos de fusión después de la exposición al medio marino, mientras que el TGA no mostró cambios en las tendencias de la curva. El FTIR mostró que no apareció nueva banda, ni desplazamiento, ya que las vibraciones de los enlaces covalentes de los grupos están presentes independientemente de la biodegradación. Indicando que no se observó una degradación microbiológica significativa de PBAT.

Palabras clave: Biodegradación; Polímeros; PBAT; Microorganismos; Medio marino.

\section{Introduction}

The growing concern with the disposal of synthetic polymers, observed in recent decades, due to their enormous quantity and environmental impact, has motivated the search for the development of biodegradable polymers (Andrade et al., 2021). Biodegradable polymers can offer ideal solutions in many applications, they are found in several market segments: packaging, horticulture, agriculture, automotive, consumer goods, and others, in order to reduce environmental impacts (Barreto et al., 2020).

PBAT is an aliphatic-aromatic, thermoplastic, synthetic copolyester and has an accelerated degradation process, which can degrade in a few weeks in contact with a favorable environment, through the action of natural enzymes, because its chemical structure is composed of an aliphatic fraction (adipate butadiene), responsible for its biodegradability, and an aromatic part (terephthalate), which provides good mechanical properties, having a maximum elongation of $700 \%$, as well as maintaining integrity of the polymer, making its degradation difficult (Shahlari \& Lee, 2012). PBAT has characteristics and properties that are similar to Low Density Polyethylene (LDPE), representing 29\% of biodegradable plastic production (Munhoz et al., 2021).

Its main characteristic, degradability, is due to the presence of enzymes that cause PBAT to completely degrade in a few weeks. This process has been studied for some years, and investigations are focused on degradation under variable 
environmental conditions. Kijchavengkul et al., (2010) reported the microbial activities in PBAT in a compost environment at high temperatures and $\mathrm{pH}$. Witt et al., (2001) observed that a thermophilic bacterium, Thermomonospora fusca, could monomerize PBAT at high temperature within 3-4 weeks. Some microorganisms have already been identified as PBAT degraders, Kasuya et al., (2009) tested the action of soil microorganisms from three different regions of Japan. The results showed that after 124 days $95 \%$ of the PBAT content had been mineralized to carbon dioxide and that during the initial periods the PBAT strips were in contact with soil microorganisms were covered with microbial biofilms.

Among studies found on the biodegradation of polymers, few were found in the literature using the aquatic environment as a biological fluid for the analysis of the biodegradation process. Given the above, the aim of this study was to evaluate the biodegradation of the polymer, PBAT, in a static system, using seawater from the Coastal Region of the State of Pernambuco in Brazil as a fluid.

\section{Methodology and Methods}

\subsection{Materials}

The investigation was carried out with PBAT - poly[(butylene adipate)-co-(butylene terephthalate)]. The analysis fluid used in the experiment was seawater located at ground zero, Recife.

PBAT, a modified polyester, was acquired by the company BASF under the name Ecoflex-F BLEND C1200. Some PBAT properties are shown in Table 1.

Tabele 1 - Properties of the polymer under study.

\begin{tabular}{ll}
\hline Properties & PBAT \\
\hline Density(ASTM D $\left.1238,190{ }^{\circ} \mathrm{C} / 2.160 \mathrm{~g}\right)\left(\mathrm{g} / \mathrm{cm}^{3)}\right.$ & 1,26 \\
Melting temperature $\left({ }^{\circ} \mathrm{C}\right)$ & $106-120$ \\
Elastic Module $(\mathrm{MPa})$ & 90 \\
Tensile Strength $(\mathrm{MPa})$ & 15 \\
Elongation at break $(\%)$ & $580-820$ \\
$\mathrm{~T}_{\mathrm{g}}\left({ }^{\circ} \mathrm{C}\right)$ & -30 \\
Fluidity index $(\mathrm{MFI})(\mathrm{g} / 10 \mathrm{~min})$ & $2,5-4,5$ \\
\hline
\end{tabular}

Source: Yamamoto et al. (2002).

\subsubsection{Bioreactors}

The experiments were carried out in a static system, using 3-liter glass bioreactors. The specimens were suspended by Nylon wires and attached to the lids of the bioreactors (Figure 1), so that they were exposed at the same depth in the fluid, for a period of up to 180 days. 
Figure 1 - Bioreactor of static systems.

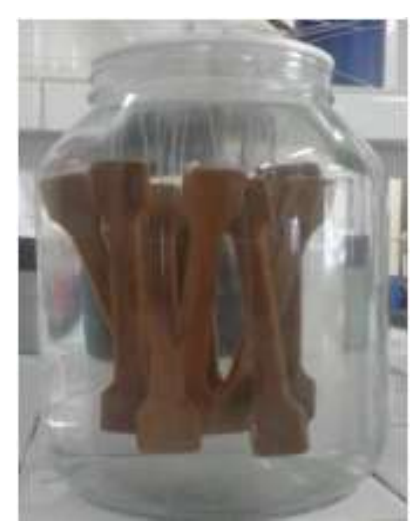

Source: Authors (2021).

Every 7, 14, 30, 60, 90, 120 and 180 days of experiments, counted from the date of assembly of the bioreactors, ten specimens, previously numbered and weighed, were removed for analysis. Planktonic microorganisms from seawater samples were also quantified.

\subsection{Methods}

\subsubsection{Sample preparation}

The PBAT was processed and injected at SENAI - CIMATEC, in an IMACON modular, twin-screw, co-rotating extruder, with L/D ratio $=30$ and screw speed equal to $250 \mathrm{RPM}$, and in an injector with a capacity of 100 tons of closing force, ROMI brand, Primax model. According to ISO 527 standards for tensile testing (ISO, 2019). Processing temperature conditions and injection conditions are shown in Tables 2 and 3, respectively.

Table 2 - PBAT processing temperature conditions in the extruder (Flow $=3.0 \mathrm{~kg} / \mathrm{h}$ ).

\begin{tabular}{cccccccccc}
\hline Sample & $\mathbf{Z 1}$ & $\mathbf{Z 2}\left({ }^{\circ} \mathbf{C}\right)$ & $\mathbf{Z 3}\left({ }^{\circ} \mathbf{C}\right)$ & $\begin{array}{r}\mathbf{Z 4} \\
\left({ }^{\circ} \mathbf{C}\right)\end{array}$ & $\begin{array}{c}\mathbf{Z 5} \\
\left({ }^{\circ} \mathbf{C}\right)\end{array}$ & $\begin{array}{c}\mathbf{Z 6} \\
\left({ }^{\circ} \mathbf{C}\right)\end{array}$ & $\begin{array}{c}\mathbf{Z 7} \\
\left({ }^{\circ} \mathbf{C}\right)\end{array}$ & Head $\left({ }^{\circ} \mathbf{C}\right)$ & Melted $\left({ }^{\circ} \mathbf{C}\right)$ \\
\hline PBAT & 130 & 135 & 135 & 140 & 150 & 160 & 170 & 170 & 175 \\
\hline
\end{tabular}

Source: Authors (2021).

Table 3 - Injection conditions.

\begin{tabular}{ccccc}
\hline Sample & $\mathbf{Z 1}\left({ }^{\circ} \mathbf{C}\right)$ & $\mathbf{Z 2}\left({ }^{\circ} \mathbf{C}\right)$ & $\mathbf{Z 3}\left({ }^{\circ} \mathbf{C}\right)$ & Beak \\
\hline PBAT & 160 & 150 & 155 & 150 \\
\hline
\end{tabular}

Source: Authors (2021).

\subsubsection{Characterization of Samples}

The PBAT before and after the biodegradation tests were evaluated by Microbiological Analysis of the surface of the samples, Mass loss, Differential Scanning Calorimetry (DSC), Fourier Transform Infrared Spectrometry (FTIR) and Thermogravimetric Analysis (TGA).

\subsubsection{Microbiological Analysis}

The quantification of the cellular concentration of microbial groups in the biofilm was carried out in the periods of 7 , 14, 30, 90, 120 and 180 days of the experiment. The following groups of microorganisms were quantified: aerobic 
heterotrophic bacteria (AHB), anaerobic heterotrophic bacteria (AnHB) and Pseudomonas sp. according to the methodology described by Silva et al., 2005; Iron precipitating bacteria (IPB) according to the methodology described by CETESB, 1988; sulfate-reducing bacteria (SRB) and filamentous fungi (FG) according to the methodology described by Postgate, 1984.

The specimens were removed from the bioreactor and placed in containers containing $30 \mathrm{~mL}$ of saline solution for aerobic microorganisms (AHB, IPB, fungi and Pseudomonas), and $30 \mathrm{~mL}$ of reducing solution for anaerobes (AnHB and SRB) and then, submitted to ultrasound for 15 seconds. The surface of the specimens was scraped with a sterile spatula in saline or reducing solution, from which $1 \mathrm{~mL}$ aliquots were removed for inoculations and dilutions. For quantification, the Most Probable Number (MPN) technique was used with dilutions up to $10^{-7}$ and counting of Colony Forming Units (CFU). All procedures were performed according to aseptic technique standards.

\subsubsection{Weight loss (Biodegradation Rate)}

The mass of the specimens was measured before and after each immersion period. The samples were weighed before and after each period on a METTLER TOLEDO XS 105 Dual Range analytical balance, with 0.01mg sensitivity. Mass loss was determined according to Equation 1 (Roy et al., 2008):

$$
\mathrm{R}(\%)=\left(\mathrm{M}_{0}-\mathrm{M}_{\mathrm{t}}\right) /\left(\mathrm{M}_{0}\right)
$$

Where: $\mathrm{M}_{0}$ the mass before biodegradation; $\mathrm{Mt}$ is the mass after the $\mathrm{t}$ biodegradation period and $\mathrm{R}$ is the percentage reduction.

\subsubsection{Differential scanning calorimetry (DSC)}

The DSC analyzes were performed in a METTLER TOLETO DSC 1 Star System equipment, at the Petrochemical Laboratory (LPQ) at the Federal University of Pernambuco. About 5 to $10 \mathrm{mg}$ of samples were placed in standard aluminum crucibles. The tests were carried out in three stages: heating - cooling - reheating. All ramps took place under a $\mathrm{N}_{2}$ atmosphere with a flow rate of $50 \mathrm{~mL} / \mathrm{min}$.

\subsubsection{Fourier Transform Infrared spectroscopy (FTIR)}

The spectra of the PBAT samples were obtained by infrared spectroscopy (FTIR), using a Thermo Scientific Nicolet model 32 spectrometer IS10, carried out at the State University of Santa Cruz-Ilheus-BA. Spectra with a resolution of $4 \mathrm{~cm}^{-1}$ and wavenumber range from 4000 to $400 \mathrm{~cm}^{-1}$ were obtained. Data were translated using the Origin 8.5 software, adjusting the baseline and normalizing. To calculate the carbonyl index (CI) Equation 2 was used.

$$
I C=\frac{A b s_{b=0}}{A b s_{b}-H}
$$

IC being the carbonyl index, $\mathrm{Abs}_{\mathrm{C}=\mathrm{O}}$ the absorbance of the carbonyl band and $\mathrm{Abs}_{\mathrm{C}-\mathrm{H}}$ of the $\mathrm{C}-\mathrm{H}$ band chosen as reference.

\subsubsection{Thermogravimetric Analysis (TGA)}

The thermogravimetric analysis was carried out in a METTLER TOLETO TGA 2 Star System equipment, the test was carried out at the Petrochemical Laboratory (LPQ) at the Federal University of Pernambuco. The heating ramp was from 30 to $600{ }^{\circ} \mathrm{C}$ with a heating rate of $10{ }^{\circ} \mathrm{C} / \mathrm{min}$, nitrogen atmosphere with a gas flow of $50 \mathrm{ml} / \mathrm{min}$. Approximately $5 \mathrm{mg}$ of the material was used in a $40 \mu \mathrm{L}$ alumina crucible. 


\section{Results and Discussion}

\subsection{Microbiological Analysis}

\subsubsection{Seawater Plankton Bacteria}

Cellular concentrations of planktonic heterotrophic aerobic (AHB), iron precipitant (IPB), anaerobic heterotrophic $(\mathrm{AnHB})$ and sulfate reducing (SRB) bacteria present in seawater were quantified and shown in Figure 2.

Figure 2 - Quantification of plankton bacteria in seawater used in the experiment.

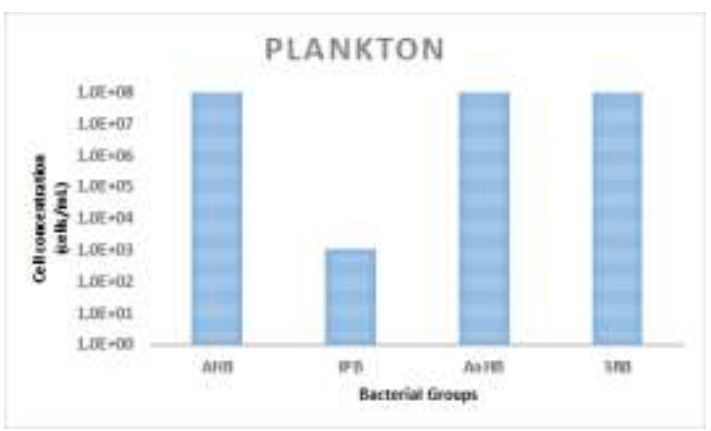

Source: Authors (2021).

The highest concentrations found were of AHB, AnHB and SRB, all in the order of 108 cells $/ \mathrm{ml}$. In smaller quantities are the IPB, with a concentration of around 103 cells $/ \mathrm{ml}$. In the literature, other studies were found for the concentration of microorganisms in seawater at the port of Recife-PE: Argolo et al., (2015) quantified the same microbial groups and obtained values of around 106 cells/ml for AHB and IPB, 105 cells $/ \mathrm{ml}$ for AnHB and 103 cells/ml for SHB. Ferreira et al., (2016) found concentrations in the order of 104 cells $/ \mathrm{mL}$ for AHB, 103 cells $/ \mathrm{mL}$ for IPB and AnHB, and 101 cells $/ \mathrm{mL}$ for SRB. The presence of these bacteria in seawater evidences a potential environment for the occurrence of biodegradation. These analyzes can generate different results, as it is influenced by location, season, weather conditions and other factors (Videla, 2003; Dutra, 2017).

\subsubsection{Sessile Bacteria in Different Systems}

Figure 3 shows the results of the microbiological analyzes of the biofilms formed on the surfaces of the specimens, in the periods of $7,14,30,90,120$ and 180 days for PBAT.

Figura 3 - Sessile microbial quantification of specimens of the system at all times studied a) AHB, IPB, AnHB and SRB and b) Filamentous fungi and Pseudomonas sp.

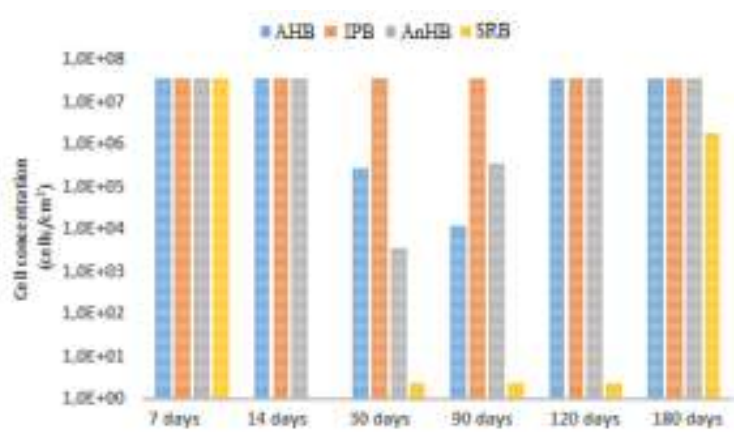

(a)

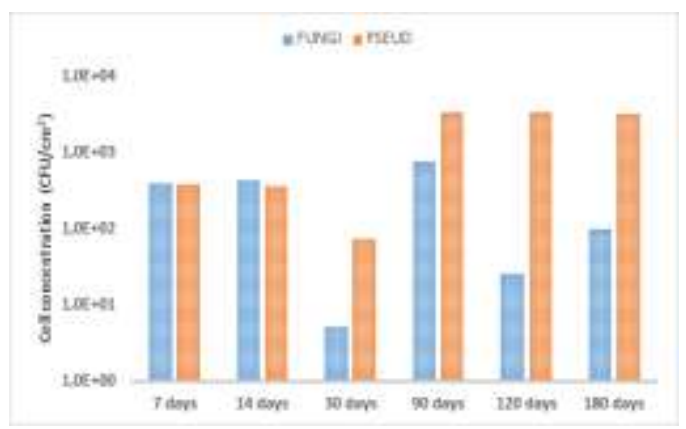

(b)

Source: Authors (2021). 
According to Figure 3a, it is possible to observe that the sessile AHB and AnHB were quantified in the system at all times of analysis, however, there was a reduction in the concentration of these microorganisms, from the $30^{\circ}$ and $90^{\circ}$ days of exposure of the specimens to the medium . Returning to quantify in $120^{\circ}$ days and $180^{\circ}$ days in the order of $10^{8} \mathrm{cells} / \mathrm{cm}^{2}$. This behavior can be explained by the exchange of water that occurred in the system every 14 days, which may have caused displacing and renewal of the biofilm, changing the nutrients and concentrations of microorganisms (Dutra, 2017).

The concentrations found at all times for IPB were in the order of $10^{8}$ cells $/ \mathrm{cm}^{2}$. SRB, on the other hand, had lower concentrations compared to other bacterial groups, only being detected in high concentrations on the $7^{\circ}$ day, not being quantified on the $14^{\circ}$ day, suffering a small increase on the $30^{\circ}, 90^{\circ}$ and $120^{\circ}$ day. Requantifying around $106 \mathrm{cells} / \mathrm{cm}^{2}$ at the end of 180 days of the experiment, probably because there was an increase in bacterial biomass and the biological demand for oxygen favored the appearance of anaerobic reducing zones, which are associated with the sulfate reduction process and the presence of BRS (Characklis \& Marshall, 1990; Wimpenney, 2000).

According to Figure $3 \mathrm{~b}$ there was the quantification of fungi and Pseudomonas at all times studied, observing a concentration in the order of $10^{3}$ cells $/ \mathrm{cm}^{2}$ from the $90^{\circ}$ day for Pseudomonas.

Many bacterial species are important for the degradation of polymers of the polyester class because they produce lipase enzymes, in particular the Pseudomonas. These enzymes play a fundamental role in the hydrolysis reactions of the ester groups present in the chemical structure of PBAT, the amorphous part of the polymer structure is more susceptible to the action of enzymes, initiating the process of breaking the bond in the initial stage of polymer biodegradation (Wu \& Gan, 1998; Tserki $e t$ al., 2006).

\subsection{Weight loss}

Figure 4 shows the evolution of PBAT mass loss over 180 days of the experimente.

Figure 4 - Degradation rate of PHB and HDPE over 180 days.

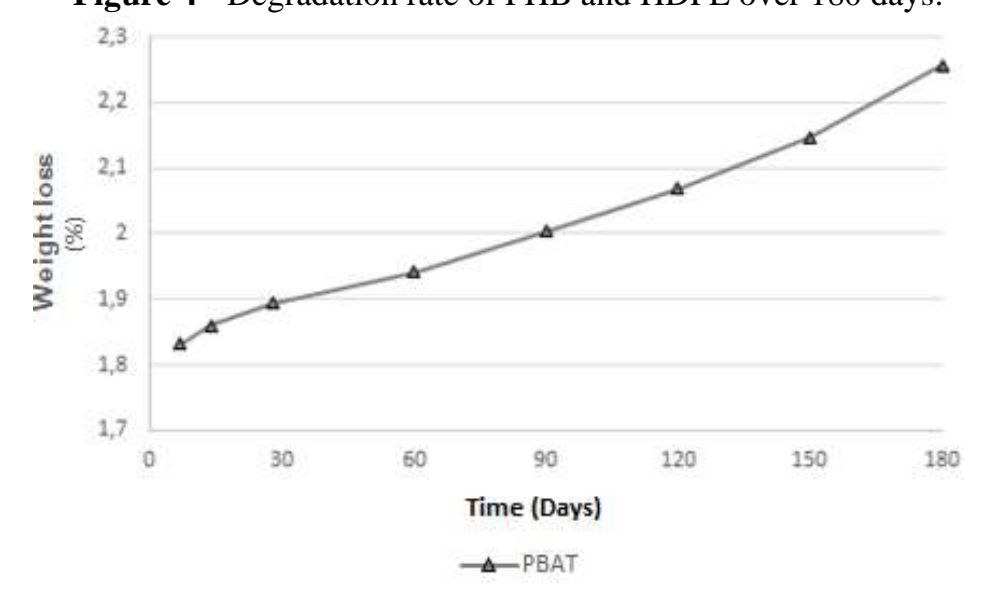

Source: Authors (2021).

At the end of 180 days of the specimens submerged in sea water, the PBAT presented a mass loss of approximately $2.3 \%$. With regard to PBAT, only a few studies have been carried out to assess its biodegradability in seawater at room temperature conditions. However, a similar behavior was found by Wang et al., (2018) where a loss of less than 2.5\% of its weight was observed in more than 56 weeks of immersion in tanks with natural sea water. Delacuvellerie et al., (2021) identified a loss of $1.5 \%$ after 82 days of immersion where PBAT was submerged in situ in the sediment and water column of the Mediterranean Sea. In soil Moraes, (2020), reported that at the end of the test, 168 days of the films buried in the soil, the pure PBAT films presented a mass loss of $33 \%$. 
Through mass loss analyses, it was observed that biodegradation can be favored, depending on the microbiota of the fluid, exposure to abiotic agents and the structure of the polymers.

\subsection{Differential Scanning Calorimetry (DSC)}

DSC analyzes were used to investigate PBAT crystallization and melting events before and after exposure to the marine environment for periods of 7, 14, 30, 60, 90, 120 and 180 days. The samples were initially heated to erase the thermal history, then rapidly cooled and heated again.

PBAT (Figure 5 and Table 4) crystallizes around $89.5^{\circ} \mathrm{C}$ and melts at approximately $126.08^{\circ} \mathrm{C}$ and it is possible to visualize a broad peak. According to Kuwabara et al., (2002), the broad melting peaks may indicate that the crystalline regions of PBAT are neither ordered nor rigid, as confirmed in their studies of atomic force microscopy, solid state carbon nuclear magnetic resonance and XRD. Magnification of melting peaks after exposure to the marine environment can be seen, in some cases it is probably caused by changing the size distribution of the crystallite.

Figura 5 - PBAT DSC curve before and after biodegradation.

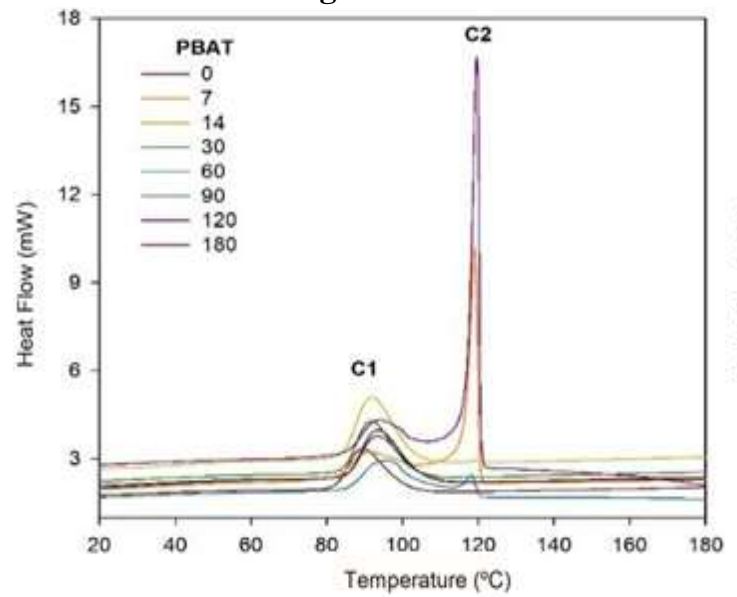

(a)

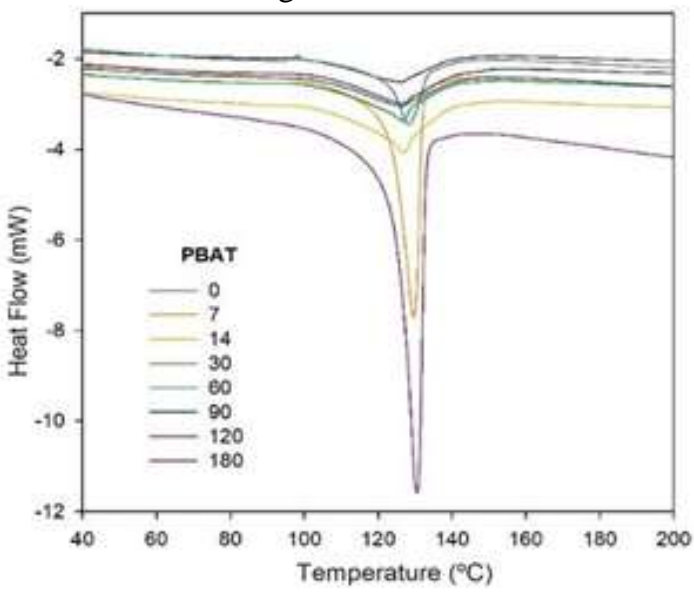

(b)

Source: Authors (2021).

According to Wang et al., (2011), microbial attack on the PBAT adipate butylene units makes the crystals present in the polymer more orderly, since PBAT forms mixed crystal structures of butylene adipate butylene terephthalate units. The oscillation of the degree of crystallinity may indicate that the crystalline regions were also reorganized by the enzymatic attacks of microorganisms. 
Table 4 - Melting temperature (Tf) and crystallization (Tc), degree of crystalline (Xc) and fusion enthalpy ( $\Delta \mathrm{Hf})$, and crystallization $(\triangle \mathrm{Hc})$ for all polymers obtained through DSC.

\begin{tabular}{ccccccc}
\hline & Days & $\begin{array}{c}\mathbf{T}_{\mathbf{c}} \\
\left({ }^{\mathbf{o}} \mathbf{C}\right)\end{array}$ & $\begin{array}{c}\Delta \mathbf{H}_{\mathbf{c}} \\
(\mathbf{J} / \mathbf{g})\end{array}$ & $\begin{array}{c}\mathbf{T}_{\mathbf{m}} \\
\left({ }^{\mathbf{o}} \mathbf{C}\right)\end{array}$ & $\begin{array}{c}\Delta \mathbf{H}_{\mathbf{m}} \\
(\mathbf{J} / \mathbf{g})\end{array}$ & $\begin{array}{c}\Delta \mathbf{X}_{\mathbf{m}} \\
(\boldsymbol{\%})\end{array}$ \\
\hline PBAT & 0 & 89,56 & 17,43 & 126,1 & 12,52 & 10,99 \\
& 7 & $118,99 / 91,6$ & 46,07 & 129,5 & 41,54 & 36,44 \\
& 14 & $118,7 / 91,91$ & 18,04 & 127,0 & 13,17 & 11,55 \\
& 30 & 91,80 & 18,66 & 126,6 & 13,30 & 11,67 \\
& 60 & $118,10 / 95,6$ & 22,69 & 128,2 & 17,29 & 15,16 \\
& 90 & 93,45 & 18,34 & 126,5 & 12,85 & 11,27 \\
& 120 & $119,6 / 94,1$ & 55,17 & 130,5 & 46,69 & 40,96 \\
& 180 & 93,54 & 17,39 & $126,2 / 141,8$ & 12,56 & 11,02 \\
\hline
\end{tabular}

Source: Authors (2021).

\subsection{FTIR}

The PBAT spectra (Figure 6) indicate the FTIR measurements of the polymer before and after the biodegradation test. Note the presence of vibrational stretches at $2954 \mathrm{~cm}^{-1}$, which is attributed to the axial deformation of the C-H bond of aliphatic carbon. The characteristic band of the C-O group in the ester bond at $1270 \mathrm{~cm}^{-1}$, furthermore, it is possible to observe characteristic bands of $\mathrm{C}=\mathrm{O}$ stretching at $1710 \mathrm{~cm}^{-1}$ and the $\mathrm{CH}_{2}$ group at $728 \mathrm{~cm}^{-1}$, as previously reported (Yanming, et al., 2012; Shankar \& Rhim, 2016; Palsikowski et al., 2018; Nikolić, et al., 2017; Venkatesan \& Rajeswari, 2017; Jiang, et al., 2020).

Figure 6 - Initial PBAT FTIR spectrum, PBAT 7 days, PBAT 14 days, PBAT 30 days, PBAT 60 days, PBAT 90 days, PBAT 120 days, and PBAT 180 days in seawater. In the range of $4000-400 \mathrm{~cm}^{-1}$.

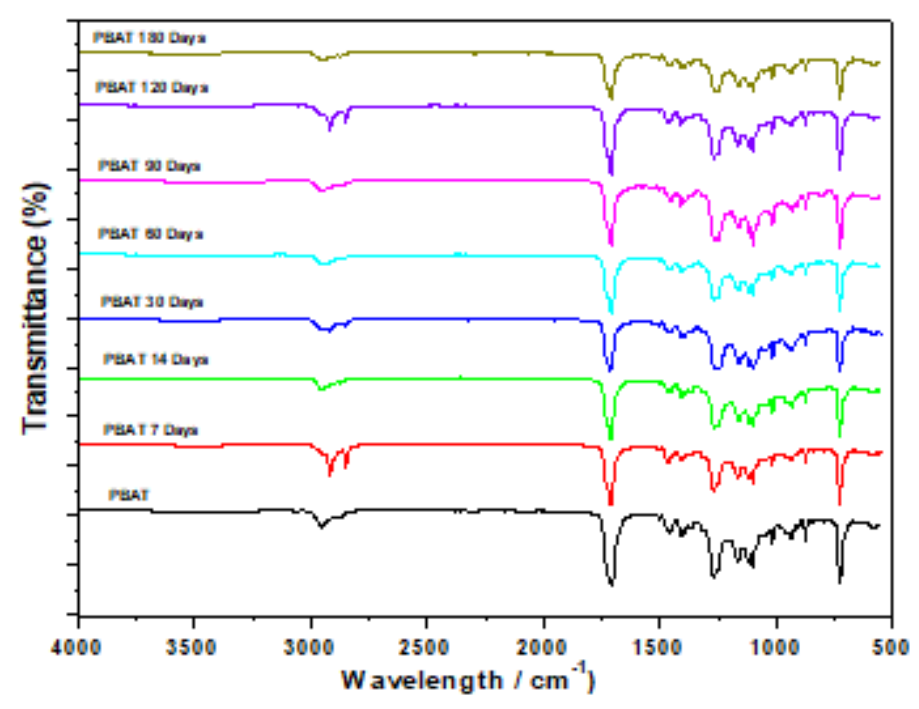

Source: Authors (2021).

Comparing the PBAT spectra before and after the biodegradation test, it can be seen, from Figure 6, that no new band appears, nor shifts, since the vibrations of the covalent bonds of the groups are present regardless of the biodegradation. In a similar study of structural characterization by FTIR was carried out by Palsikowski et al., (2018) and Moraes, (2020), who also did not detect significant changes in the PBAT absorption bands.

Therefore, to characterize the change in molecular structure, carbonyl indices were calculated through equation 2 and the results are shown in Table 5. 
Table 5 - PBAT carbonyl indices after biodegradation.

\begin{tabular}{cccc}
\hline Sample & $\mathbf{C = O}(\mathbf{1 7 1 0})$ & $\mathbf{C - H} \mathbf{( 1 4 1 0 )}$ & IC \\
\hline PBAT & 6,096 & 6,296 & 0,968 \\
PBAT 7 days & 6,243 & 6,543 & 0,954 \\
PBAT 14 days & 6,247 & 6,535 & 0,956 \\
PBAT 30 days & 6,295 & 6,536 & 0,963 \\
PBAT 60 days & 6,264 & 6,536 & 0,958 \\
PBAT 90 days & 6,171 & 6,489 & 0,951 \\
PBAT 120 days & 6,151 & 6,538 & 0,941 \\
PBAT 180 days & 6,375 & 6,551 & 0,973 \\
\hline
\end{tabular}

Source: Authors (2021).

Analyzing the evolution of the carbonyl index, it is noted that there was no significant change in the material under study. Usually, the structural change occurs by monitoring the terminal carboxylic groups, however this measure can be difficult to identify if these new structures reorganize, masking the chemical changes in the polymer. As PBAT has carbonyl in its main chain, if the microbiological attack hydrolyses the ester-type bonds, the total number of carbonyl will not change, however alcohol will be produced by hydrolysis. But if hydrolysis occurs at another bond, new carbonyls will form. In addition, there may be formation of carboxylic acids during hydrolysis, which can be assimilated by microorganisms, resulting in a decrease in the carbonyl index (Moraes, 2020).

Therefore, the increase or decrease in the carbonyl index is related to the chemical environment, the stage of degradation of the material and the biota of the sea water to which the polymer was exposed.

\subsection{Thermogravicmetric Analysis (TGA)}

Figure 7(a) shows the thermal decomposition curve of the PBAT polymer during 180 days.

Figure 7 - PBAT decomposition thermograms (a) and (b) from zero to 180 days.

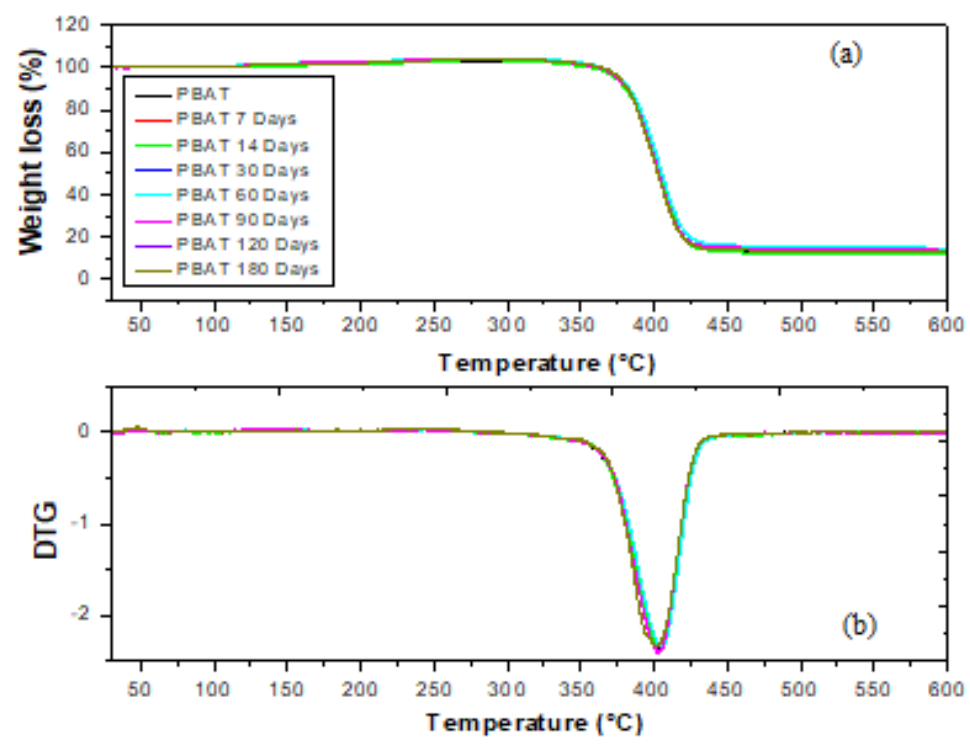

Source: Authors (2021).

The degradation of PBAT, as shown in Figure 7(a) happened abruptly. The 180-day exposure time in seawater did not change the trend of the curves: all of them had near maximum degradation temperatures. This behavior shows that most bonds present in the chemical structure of the polymer are present. However, larger splits in the PBAT main chain could be favored, 
probably, if the production of extracellular lipases were required. In this context, the addition of nutritional supplements such as fats or fatty acids would be valuable for inducing lipase excretion and, consequently, more pronounced degradation in PBAT.

Table 6 shows data on thermal degradation that can be obtained from the curves in Figure 7. Temperature onset (TONSET) and end (TENDSET) of degradation were obtained by the intersection of tangents to the curves in the respective region of interest (Figure 7a ). The maximum degradation temperature was obtained by reading the peak obtained in Figure 5 b.

Table 6 - Tonset, Tendset e Tmax values of the main stage of PBAT thermal degradation.

\begin{tabular}{ccccc}
\hline Amostras & Tonser $^{\left({ }^{\mathbf{O}} \mathbf{C}\right)}$ & Tendset $\left({ }^{\mathbf{O}} \mathbf{C}\right)$ & Tmáx $\left({ }^{\mathbf{}} \mathbf{C}\right)$ & Massa residual $(\boldsymbol{\%})$ \\
\hline PBAT & $\mathbf{3 8 1 , 8}$ & $\mathbf{4 1 9 , 9}$ & $\mathbf{4 0 6 , 7}$ & $\mathbf{1 2 , 4}$ \\
\hline PBAT - 7 dias & 382,2 & 418,2 & 406,2 & 11,6 \\
\hline PBAT - 14 dias & 383,6 & 419,6 & 406,2 & 11,6 \\
\hline PBAT - 30 dias & 384,1 & 420,7 & 406,3 & 15,4 \\
\hline PBAT - 60 dias & 381,7 & 419,8 & 405,7 & 12,8 \\
\hline PBAT - 90 dias & 384,2 & 419,1 & 406,0 & 9,0 \\
\hline PBAT - 120 dias & 381,9 & 418,1 & 406,0 & 14,2 \\
\hline PBAT - 180 dias & 381,8 & 417,5 & 406,7 & 12,3 \\
\hline
\end{tabular}

Source: Authors (2021).

It can be said that degradation started around $382{ }^{\circ} \mathrm{C}$ and ended around $419{ }^{\circ} \mathrm{C}$ for most samples. The maximum degradation rate was obtained around $406^{\circ} \mathrm{C}$ and the residue ranged from 9 to $15 \%$.

Zehetmeyer et al., (2016) found two stages of thermal degradation. The first, which coincides with the one found in this work, which may be due to the maximum decomposition of the adipic acid aliphatic copolyester and 1,4-butanediol, and the other stage around $600{ }^{\circ} \mathrm{C}$ with the decomposition of the terephthalate aromatic copolyester. However, other authors found only one stage of degradation, from 350 to $430{ }^{\circ} \mathrm{C}$ (Cobo et al., 2021; Andrade, et al., 2020; Andrade et al., 2018; Arpaporn et al., 2013).

According to Morais (2020), the amount of stage in degradation can be linked to the amount of each monomer in the polymer, being those with more aliphatic units degraded in a single stage.

\section{Conclusion}

The biodegradability of PBAT in a marine environment was evaluated. The 180 days immersed in sea water influenced the composition of the microorganism community developed in the polymer. However, the signs of degradation observed were very low with no significant degradation. It was observed that the bacterial community developed on the surface of PBAT was insufficient for biodegradation and they use this polymer mainly as physical growth support, probably due to the large availability of carbon in seawater collected in the zero point region in Recife-PE. Consequently, the microorganisms did not use the polymer as a carbon source and did not assist in degradation.

It was observed through the FTIR there was no significant change in the carbonyl index, there was no appearance of any new band, or displacement, since the vibrations of the covalent bonds of the groups are present regardless of biodegradation. In relation to the TGA in 180 days of exposure to seawater, it did not change the trend of the curves: all of them had a maximum degradation temperature close to each other. And the mass loss test showed a result of approximately $2.3 \%$, which indicates that there was no significant degradation of PBAT. The current standards and norms used are insufficient to predict biodegradability in an aquatic environment. 


\section{References}

Andrade, M. F, Filho, L. E. P. T. de M, Silva, I. D. de L, Lima, J. C. da C, Carvalho, L. H, Almeida, Y. M. B, \& Vinhas, G. M (2020). Influence of Gamma Radiation on the Properties of Biodegradable PBAT - Poly (butylene Adipate co-terephthalate) Active Films with Orange Essential Oil. Macromolecular Symposia, 394(1), 200005.

Andrade, M. F, Gois, G. S, Garcia, S. M. S, Da Silva, I. D. L, Caetano, V. F, De Almeida, Y. M. B, De Melo, T. J. A, \& Vinhas, G. M. (2018). Active Packaging Using Orange Oil Incorporated into PBAT Biodegradable Films. Materials Science Forum, 930, $283-289$.

Andrade, M. F, Silva, I. D. L, Cerqueira, G. R, Almeida, Y. M. B, \& Vinhas, G. M (2021). Caracterização térmica de filmes ativos biodegradáveis de PBAT aditivados com óleo de laranja. Brazilian Journal of Development. 7(8), 85955-85964.

Argolo, E, França, F, Oliveira, S, Silva, R, Cruz, T, Queiroz, V, Urtiga Filho, S, Lima, M (2015). Biocorrosão em cupons de aço carbono AISI 1020 expostos à água do mar e óleo diesel S10/Biodiesel B6. In: Conferência sobre Tecnologia dos Equipamentos, 13, Cabo de Santo Agostinho, Anais... Abendi.

Arpaporn, T, Yupaporn, R, \& Kasama, J. (2013). Preparation and Characterization of Poly(lactic acid)/Poly(butylene adipate-co-terepthalate) Blends and Their Composite, Polymer-Plastics Technology and Engineering, 52:13, 1362-1367.

Barreto, L. S, Da Silva, E. E. G, Barbosa, J. D. V, Maciel, S. H. O, Almeida, Y. M. B, \& Vinhas, G. M (2020) Microrganismos na Biodegradação de Polímeros em Meio Aquoso. Ciência e tecnologia: estudos sobre as propriedades, processamento e produção de materiais. Artemis.

Characklis, W. G, \& Marshall, K. C. (1990). Biofilms: A basis for in interdisciplinary approach. In Characklis, W. G, Marshall, K. C. Biofilms. New York: John Wiley \& Sons. 796.

Cobo, F. N, Santana, H, \& Carvalho, G. M. (2021) Estudo da miscibilidade de blendas de poli (ácido lático)/ poli (butileno adipato-co-tereftalato) preparadas pelo método de evaporação de solvente. Revista Matéria, 26(2), 1517-7076.

Companhia de Tecnologia de Saneamento Ambiental, CETESB, [Company of Environmental Sanitation Technology, CETESB] (1988). Contagens de colônias de bactérias que precipitam o ferro, [Counting of bacterial colonies that precipitate iron], Norma L5.207, 1-20, [Norm L5.207 (1988) 1-20], Portuguese.

Delacuvellerie, A, Benali, S, Cyriaque, V, Moins, S, Raquez, J, M, Gobert, S, \& Wattiez, R. (2021). Composição do biofilme microbiano e degradação do polímero de plásticos compostáveis e não compostáveis imersos no meio marinho. Journal of Hazardous Materials, $419,126526$.

Dutra, J. C. V. (2017). Quaternários de Amônio e Quitosana no Combate à Biocorrosão so Aço Carbono em Água do Mar: Análise Microbiológica e Perda de Massa. Trabalho de Conclusão de Curso. Recife, PE: UFPE.

Ferreira, F. G. D, Silva, P, Moraes, P. H. C, Alves, A. S. S, Lima, M. A. G. A, Oliveira, S. H, \& Urtiga Filho, S. L. (2016). Efeito de biocidas na corrosão induzida microbiologicamente do aço carbono em água salina. In: (INTERCORR), 6, Búzios.

ISO 527-1:2019. Plastics — Determination of tensile properties — Part 1: General principles/ Também no catálogo da ABMT.

Jiang, G, Shuidong, F. W, \& Huang, Z. H. (2020). Structure and improved properties of PPC/PBAT blends via controlling phase morphology based on melt viscosity. Journal of Applied Polymer Science. 137, 48924.

Kasuya, K, Ishii, N, Inoue, Y, Yasawa, K, Tagaya, Y, Youtsumoto, Y, Kazahaya, J, \& Nagai, D. (2009). Characterization of a mesophilic aliphatic-aromatic copolyester-degrading fungus. Polymer Degradation and Stability, 94, 1190-1196.

Kijchavengkul, T, Auras, R, Rubino, M, Selke, S, Ngouajio, M, \& Fernandez, T. (2010). Biodegradation and hydrolysis rate of aliphatic aromatic polyester. Polymer Degradation and Stability, 95, 2641-2647.

Kuwabara, K, Gan, Z. H, Nakamura, T, Abe, H, \& Doi, Y. (2002). Crystalline/amorphous phase structure and molecular mobility of biodegradable poly(butylene adipateco-butylene terephthalate) and related polyesters. Biomacromolecules. 3(2): 390-396.

Moraes Filho, L. E. P. T. (2020). Desenvolvimento de filmes ativos de poli (butileno adipato co-tereftalato) (PBAT) e investigação da biodegradação em solo. Dissertação (Mestrado). Universidade Federal de Pernambuco, Recife- PE.

Munhoz, P. M, Nascimento, F. C, Silva, L. G. A, Harada, J, \& Calvo, W. A. P. (2021). Influence of electron beam irradiation on the mechanical properties of PBAT / PLA polymeric blend, Brazilian J. Dev., 7(8), 78782-78792.

Nikolić, M. A. L, Gauthier, E, Colwell, J. M, Halley, P, Bottle, S. E, Laycock, B, \& Truss, R. (2017). The challenges in lifetime prediction of oxodegradable polyolefin and biodegradable polymer films. Polymer Degradation and Stability, 145, 102-119.

Palsikowski, P. A K, uchnier, C. N, Pinheiro, I. F, \& Morales, A. R. (2018). Biodegradation in Soil of PLA/PBAT Blends Compatibilized with Chain Extender. Journal of Polymers and the Environment, 26(1), 330-341.

Postgate, J. R. (1984). The Sulphate-Reducing Bacteria Cambridge University Press, Cambridge, England.

Roy, P. K, Titus, S, Surekha, P, Tulsi, E, Deshmukh, C, \& Rajagopal, C. (2008). Degradation of abiotically aged LDPE films containing pro-oxidant by bacterial consortium. Polymer Degradation and Stability, 93, 10, 1917-1922.

Shahlari, M, \& Lee, S. (2012). Mechanical and morphological properties of poly(butylene adipate-coterephthalate) and poly(lactic acid) blended with organically modified silicate layers. Polymer Engineer Science, 52(7), 1420-1428.

Shankar, S, \& Rhim, J. (2016). Tocopherol-mediated synthesis of silver nanoparticles and preparation of antimicrobial PBAT/silver nanoparticles composite films. LWT - Food Science and Technology, 72, 149-156. 
Research, Society and Development, v. 10, n. 17, e164101724579, 2021

(CC BY 4.0) | ISSN 2525-3409 | DOI: http://dx.doi.org/10.33448/rsd-v10i17.24579

Silva, N, Neto, R. C, Junqueira, V. C. A, \& Silveirs, N. F. A. (2005). Manual de métodos de análise microbiológica da água, Manual of methods for microbiological analysis of water. Varela Editora e Livraria Ltda, São Paulo.

Tserki, V, Matzinos, P, Pavlidou, E, Vachliotis, D, \& Panayiotou, C. (2006). Biodegradable aliphatic polyesters. Part I. Biodegradable aliphatic polyesters. Part I. Properties and biodegradation of poly(butylenes succinate-co-butylene adipate. Polym. Degrad. Stab. 91, 367-376.

Venkatesan, R, \& Rajeswari, N. (2017). TiO2 nanoparticles/poly(butylene adipate-coterephthalate) bionanocompositefilms for packaging applications. Polymers for advanced technologies, 28, 1699-1706.

Videla, H. A. (2003). Biocorrosão, biofouling e biodegradação de materiais. Editra Eggard Blucher Ltda, 148.

Wang, X, Shi, J. Chen, Y. Shi, Y, \& Fu, Z. (2011). Nonisothermal crystallization behavior of biodegradable poly(butylene terephthalate-co-butylene adipateco-ethylene terephthalate-co-ethylene adipate) copolyester. Polym. Eng. Sci. 51, 2535-2541.

Wang, X. W, Wang, G. X, Huang, D, Lu, B, Zhen, Z. C, Ding, Y, \& Ji, J. H. (2018). Degradability comparison of poly(butylene adipate terephthalate) and its composites filled with starch and calcium carbonate in different aquatic environments. Journal of Applied Polymer Science, e46916.

Wimpenney, J. (2000). Na overview of biofilms as functional communities. In: Allison, D.G.; Gilbert, P.; Lappin-Scott, H.M.; eds, Communities, Structures and Co-operation in Biofilms. UK: Cambridge University Press, 1-24.

Witt, U, Eining, T, Yamamote, M, Kleeberg, I, Decwer, W. D, \& Müller, R. J. (2001). Biodegradation of aliphatic-aromatic copolyesters: evaluation of the final biodegradability and ecotoxicological impact of degradation intermediates. Chemosphere, v. 44, p. 289-299.

Wu, C, \& Gan, Z. (1998). A novel method of studying polymer biodegradation. Polymer, 18, 4429-4431.

Yamamoto, M, Witt, U, Skupin, G, Beimborn, D, \& Müller, R. J. (2002). Biodegradable Aliphatic-Aromatic polyesters: “Ecoflex ${ }^{\circledR}, 299$.

Yanming, C, Jungang, L, Jimin, F, Young, L, Zhaohng, W, Meng, Z, \& Ronggunang, S. (2012). Discrimination of Poly(butylenes adipate-co-terephthalate) and Poly(ethylene terephthalate) with Fourier Transform Infrared Microscope and Raman Spectroscope. Spectroscopy letters: An International Journal for rapid Communication, pp.280-284.

Zehetmeyer, G, Meira, S. M. M, Scheibel, J. M, De Oliveira, R. V. B, Brandelli, A, \& Soares, R. M. D. (2016). Influence of melt processing on biodegradable nisinPBAT films intended for active food packaging applications. J. Appl. Polym. Sci. 133(13), 1. 